\title{
Identification and Quantification of the Overall Impact of the National Economy on Life Assurance in the Federal Republic of Germany *
}

\author{
by Robert Schwebler**
}

I.

Despite the increasing importance of the economic environment for insurance, a systematic and empirically based identification and quantification of the complex structure of the factors influencing this industry is still not available. There are numerous individual publications concerning individual aspects, especially the evolution of the population and the effects of a decreasing value of money and social policies. The question related to the capital investment policy of insurers have also been broadly dealt with in literature. However, it is only in recent years that initial attempts have been made to describe regarding some segments of insurance - the complex structure of influencing factors as a whole and their interdependence.

This paper is intended to present a model describing the effects of the overall structure of economic influences on the trend of business in life assurance in the Federal Republic of Germany.

II.

From the advent of economic research in Germany it has never been contested that there is a correlation between the trend of business in life assurance and the development of the economy. Dr. Arnold Otting, for instance, states in his paper "Business Cycle and Life Assurance" (1927) that as soon as the life assurance market has reached a certain degree of saturation, it becomes completely dependent on the development of the economy. But economists have never gone deeper into this fundamental idea. Authors mainly confined themselves to showing certain parallelism between premium income and the national product in order to prove the dependence of insurance on economic cycles.

* An abridged version of a lecture given at the Symposium "Money, Banking Institutions and Insurance " held by the University of Karlsruhe in December 1982.

** Managing Director and Chairman of the Board of the Karlsruher Lebensversicherung AG, Karlsruhe ; Professor at the University of Karlsruhe. 
III.

Before entering into a detailed discussion of the economic factors influencing insurance, let me first provide a survey of the previous trend of business in life insurance.

After the Second World War life assurance in the Federal Republic experienced a rapid recovery. To this very day it has remained a "growth industry" in terms of premium income. The pace of premium growth, however, in terms of the annual rate of change, has gradually slowed down, thus following the slackening of the economy as a whole. While in the early sixties the annual premium growth rates amounted to $15 \%$, they fell to $10 \%$ in the late seventies. In real terms the difference would be even larger, since the decrease in the value of money is greater today than it was 20 years ago.

Premium income has by no means increased steadily. Its growth is rather characterized by cyclical fluctuations with considerable deviations. On the basis of the usual definition of a cycle according to which a cycle comprises successive years of recovery, i.e. years with an increasing growth rate, and years with a downward trend, i.e. years with a declining growth rate, five premium cycles can be established for the period from 1959 to 1980 . A premium cycle normally comprises four to five years. A comparison of premium cycles and economic cycles shows, despite certain special factors inherent to the insurance industry, that the periodicity and succession of phases are relatively congruent.

Apart from premium income as a basic indicator of business trends, the incurred on surrenders expenditure as well as the business in force and the new business in terms of sums insured are analysed in the following. The respective number of contracts was not included, since this figure is less instructive with regard to the development of premiums. The diagram shows that the business in force in terms of sums insured takes a course similar to that of the premium income. This applies both to the trends of development and the succession of cycles as well as to the extent of fluctuations. Hence, the "cycles of business in force" also correspond fundamentally with the cycles of the overall economy.

The expenditure incurred on surrenders, i.e. the surrender values paid for insurance contracts cancelled before maturity, vary to quite a considerable extent. It is very difficult to determine the succession of cycles, as years with an upward and downward tendency often come in immediate succession. Despite these irregular fluctuations a certain correlation with the economic trend can be found. Economic slumps go along with a significant increase in surrenders expenditure $(1967,1974 / 75,1981)$.

Similar with regard to new business in terms of sums insured statements can be made. Such new business, which from 1960 to 1980 increased at an average annual rate of $14 \%$, also shows a cyclical course, which, apart from exceptional years, comes close to the trend of the economy as a whole. The exceptions in this case were mainly due to "exemption measures " and the inclusion of life assurance into the "law relating to asset formation". In general it has to be concluded, however, that new business fluctuated to a much broader extent than for instance the premium income.

The analysis will seek to determine the reasons for this parallelism between economic development and the trend of business in life assurance. While the development of the national product suggests at first sight that economic production and the resulting incomes 
The cycles of the gross national product in real terms and of premium income in life assurance

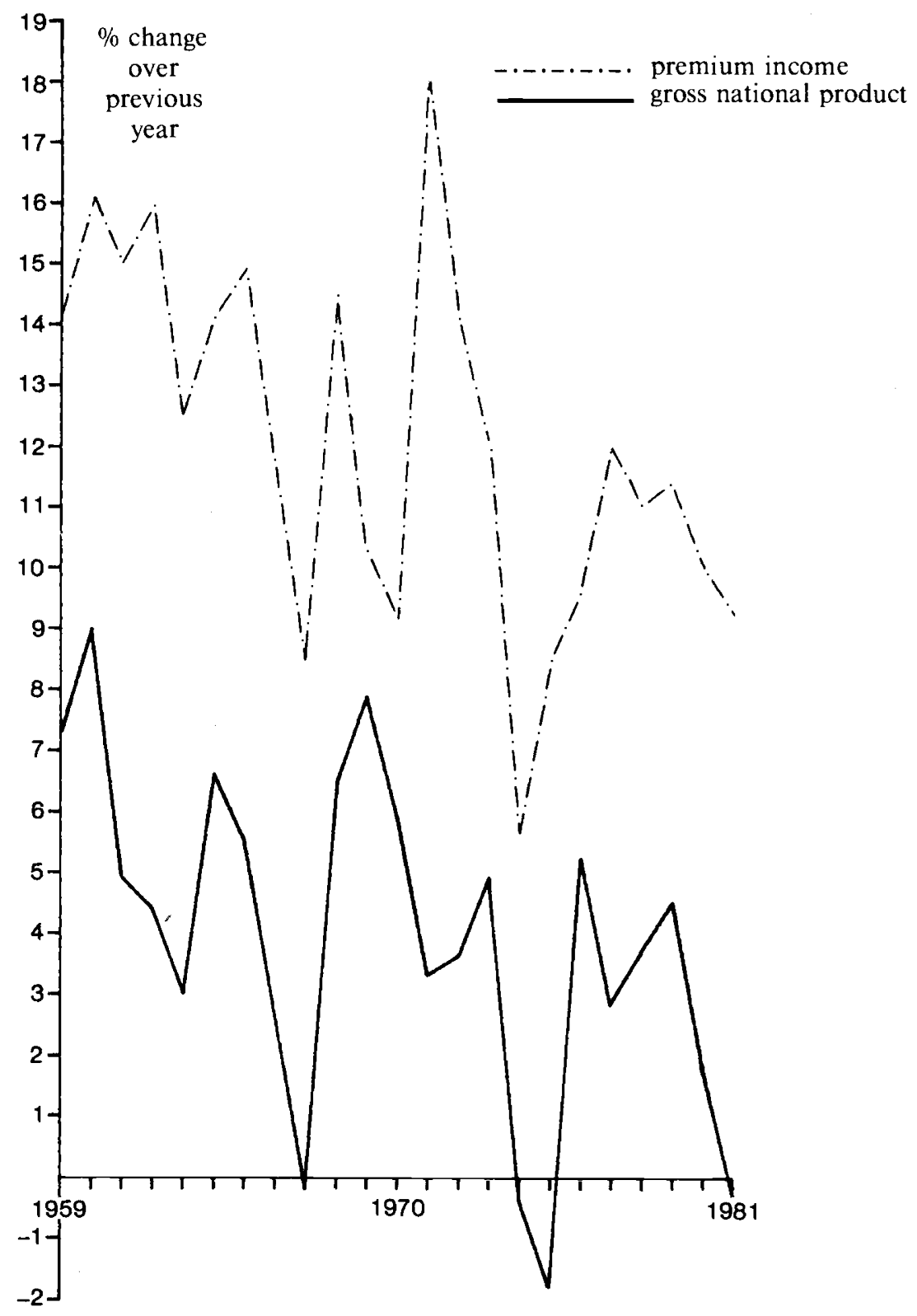


are transferred directly to life assurance business, it is still necessary to identify and quantify the exact factors causing this transfer, and thus to establish a possibly much closer relation between the development of economic factors and the indicator of the life assurance business as would have been possible on the basis of the gross national product alone.

\section{IV.}

It is generally assumed that the development of prices and incomes, economic growth and investment activities, demographic evolution and employment as well as economic and socio-political measures are of particular importance for the insurance industry.

The social policy of a country creates the basic conditions for the development of the life assurance industry. There is a continuous correlation between life assurance, on the one hand, and the extent to which the population is burdened with social charges as well as the scope of cover offered by the state insurance scheme, on the other. However, a distinction must be made between the consequences of less important and more frequent modifications of the premium rate and the scope of cover, as opposed to measures which have resulted in certain structural breaks in the development of life assurance.

When taken alone the increase in social charges is likely to have a negative effect on the financial capacity of the individual to take care of his own social protection. It is true, however, that progressive life assurance linked to the rising income ceiling for the calculation of pay-related social insurance contributions has positive effects as long as the development of earnings leaves room for this additional expenditure for social protection. This may doubtlessly be assumed with regard to the past. With stagnating or even declining real incomes, however, as is the case at the present, it is quite likely that increasing contributions do have a negative effect on the individual's possibilities of providing himself with social protection.

A change in the fundamental orientation of a country's social policy will presumably have a much greater impact than the socio-political effects described above. During the last 20 years there have been two events which deserve special mention:

First, the 1968 exemption scheme, which exempted employees from compulsory insurance provided they took out an adequate private life assurance : second, the inclusion of life assurance into the range of facilities under the 624 DM Law at the end of 1970. Both events essentially changed the basic conditions for life assurance.

In the long run these conditions are also established by demographic developments (size of the population, number of households, number of marriages, birth rate, etc.), which are probably of secondary importance for a short- and medium-term analysis of business trends. But even short-term correlations (as between marriages and new business) cannot be excluded entirely.

In a broader sense, employment, too, is a demographic indicator. It certainly also has a more short-term correlation with life assurance. The number of employed persons, in turn, depends fundamentally on the situation in the labour market, which will be considered more closely below. 
The main topic of this analysis is the question to what extent life assurance depends on economic influences, especially cyclical fluctuations.

In particular, the following indicators of economic development were studied with regard to their importance for life assurance : economic growth, development of earnings, decreasing value of money, savings activity, various types of financial investments and employment situation.

The development of the production capacity of a national economy is most broadly reflected by the economic growth measured in terms of the changing national product. Even though the national product does not seem to be, in the strict sense, a causal influencing factor with regard to life assurance, it may be understood as a combination of a multitude of economic factors. In general, a more rapid pace of economic growth is likely to have positive effects on new business and thus on the development of premium income and the business in force. The opposite effect could be expected when the development is slowing down. The relation between economic development and the expenditure incurred on surrenders would appear to be the other way round.

A technically more direct relation than between life assurance and the national product exists between life assurance and the development of incomes. The growth, for instance, of the disposable income of private households or of the net amount of wages and earnings has a substantial impact on the capacity to make provision for old age and thus on the margin of growth of life assurance. A similar correlation can be assumed between the development of incomes and the development of contributions and sums insured.

As life assurance is largely a long-term savings activity it would be adversely affected by a sustained decrease in the value of money. However, it is necessary to make distinctions according to the extent to which prices increase or the value of money goes down. As long as the rate of monetary depreciation is felt to be tolerable, it is reflected in life assurance by nominal increases in premiums and sums insured. Besides, with a moderate decrease in the value of money life assurance appears to be a relatively advantageous type of investment. Up to now the decreasing value of money has been more than compensated by regular premium adjustments and profitsharing, so that the real value of the funds invested has been maintained.

If, however, the rate of inflation would rise beyond a certain level, this would not inevitably have adverse effects on life assurance, as we can learn from experience gained in other countries. At least a structural shift from endowment assurance to pure term assurance would be probable. This would mean that the insured would no longer provide for their security in the case of survival but would rather confine themselves to covering the pure death risk.

It seems, however, that life assurance is even more dependent of the use than on the development of incomes. The share of a person's income not spent on consumption, i.e. his savings, represents the real potential of the life assurance business. While the savings ratio, i.e. the percentage of savings related to the disposable income of private households, increased substantially up to the mid-seventies, it has now levelled off at a somewhat lower standard. With a smaller growth in income together with the decreasing share of savings in a person's income, the savings activity has probably only been a weak stimulus for the growth of the life assurance business in recent times. 
With regard to the formation of savings it is of particular interest to establish which factors are decisive for the share of life assurance in the total savings activity. In this respect the return provided by a specific type of investment, the extent to which it is protected against a decreasing value of money, as well as its mobility and security seem to be important criteria on which the decision is based. However, it has to be considered that the different types of investment can substitute one another only up to a certain point. Life assurance is a typical long-term type of saving; it is the only type of investment to provide immediate protection against risks and it offers a high stability of value. Alternative types of investments will normally only compete with new business.

Changes in the labour market also seem to have a considerable significance for the life assurance business. Increasing employment and job security, the typical features of the development in the Federal Republic of Germany up to the early seventies, created a favourable environment for life assurance. Conversely, declining employment and a rise in unemployment seem to have an adverse effect on the life assurance business. A decrease in the rate of employment is not only reflected by new business, but also makes itself felt in the premium income derived from existing contracts due to exemptions from premium payment and lapses.

The extent to which the feelings and expectations of the persons involved in the economic process influence their behaviour with regard to decision-making, has been illustrated by many examples. Time and again, this raises the problem of quantifying these factors, especially with regard to life assurance. And yet, feelings and expectations certainly play an important role, particularly in respect of a long-term commitment such as an individual's provision for old age by means of a life assurance contract. It is, however, possible that such feelings and expectations have ambivalent effects, since the wish for more protection can be engendered by a positive as well as a negative outlook.

Applying the "Allensbach Indicator" 1 and the index of the so-called "consumption climate" one has at least two figures out of the meagre supply of time series that may be used as indicators for the psychological climate in society. The Allensbach Indicator shows whether a representative segment of the population is hopefully or anxiously looking forward to the new year. The indicator of the consumer's opinion is determined on the basis of the periodical consumer polls conducted by the Society for Consumption and Sales Promotion. In these interviews private households are asked how they appreciate their own economic situation and the present and future economic development.

In order to avoid the impression, which possibly has arisen from the above that life assurance is subject only to overall economic factors, it should be expressly stated that there is quite a number of effective industry- and company-related strategic instruments which can be used in order to exert on the trend of business.

Product engineering, product innovation, publicity and sales methods can be mentioned as a few examples. But these fields of activity, however important they may be for the position of the individual company, cannot be the subject of the present study, which deals with the identification and quantification of the economic factors influencing life assurance.

1 Named after the "Allensbach opinion poll agency". 
The purpose of the preceding feasibility considerations was to explain that economic influences are passed on to the insurance industry by factors which can be individually specified. It is, however, not possible to describe their isolated effects as in a physical model. The development of the insurance industry is always the result of a combination of all influencing factors. In view of the complex structure of the influencing factors it was not to be expected anyway, that the business trend of life assurance could be described with sufficient reliability on the basis of a single factor. This has been positively proved by the simple correlation analysis method generally used to measure the correlation between a dependent and an independent variable. The correlation coefficient, i.e. the measure of the intensity of the correlation between the dependent insurance variable and the general economic factors examined, reached a value of 0.6 in only a few cases, thus not even explaining $40 \%$ of the variance of the insurance variable. If the standards applied are less strict and correlation coefficients of 0.3 to 0.4 are accepted as indicating the existence of a correlation, it can be demonstrated that, for instance, the development of premium income is correlated above all with income and savings variables, economic data and the psychological climate in society. With regard to surrenders and new sums assured in life assurance the values of the correlation coefficients normally do not allow even such a statement.

Applying a factor analysis in order to identify and quantify the most important influencing factors one is able to reduce - in a manner quite satisfactory in formal terms - the factors influencing the trend of business in life assurance to a few economic parameters. According to this model the basic factors which influence the life assurance business are :

- the economic cycle;

- the development of incomes ;

- the psychological climate in society.

On the basis of the results of the factor analysis it was possible to formulate a number of multiple regression statements which describe nearly $90 \%$ of the development of the insurance indicator. (For more details refer to "Gesamtwirtschaftliche Einflüsse auf die Lebensversicherung ", in Schriftenreihe des Ausschusses Volkswirtschaft des Gesamtverbandes der Deutschen Versicherungswirtschaft, Heft 1, Verlag Versicherungswirtschaft, Karlsruhe 1983.)

The values of the absolute term and the regression coefficient of the linear equation for premium incomes - or, more precisely their percentage change over the previous year - were estimated on the basis of data from the years 1965 to 1980 included in the reference period. These estimates are shown in the tables attached.

Statistics were applied with very satisfactory results in order to trace the development of premium income in life assurance by an appropriate combination of the national product, the development of prices, the savings ratio and "Allensbach Indicator". The Dummy Variable is used only to eliminate the special influences of social and political measures which otherwise would have distorted the context of events observed.

In the same way multiple regressions have been formulated for the expenditure incurred on surrenders, the business in force and the new business in terms of sums insured, 
each compared with the annual rates of change. These variables were also described statistically with satisfactory results by an appropriate combination of economic factors.

- Surrenders expenditure: It was possible to mathematically relate more than $80 \%$ of the fluctuations in surrenders expenditure to economic variables (such as incomes, price increase, unemployed, general attitude among the public).

- Sums insured currently in force: More than $80 \%$ of the rates of change of the sums insured currently in force were determined on the basis of the national product in nominal terms, the unemployment rate, savings ratio and Allensbach Indicator.

- New sums insured: Here again, more than $80 \%$ of the fluctuations of new business were calculated from the nominal national product private consumption, Allensbach Indicator and previous new business (the so-called delayed endogenous variable).

The different equations and their diagrams are to be found in the addendum.

VI.

Considering the relatively good adjustment of the actual development of insurance variables by applying appropriate estimators, the regression statements will be examined below with a view to their possible prognostical value.

By reference to the existing statements based on the reference period from 1965 to $1980 / 81$, projected figures were calculated for the years 1981 and 1982. Even though these figures no longer have any genuine prognostical function, they provide an initial indication of whether or not the statements set forth suit the purpose of projection. The figures to be indicated below would have been used, at the end of 1980 and 1981 , to estimate the development in each of the following years.

For the year 1981 the following growth rates are calculated on the basis of the regression statements : premium income 5 to $7 \%$, surrenders between 30 and a good $40 \%$, sums insured in force 9 to $10 \%$ and new sums insured $0 \%$. While the deviations between the projected and the real figures with regard to premium income $(9.3 \%)$ and new business $(3.8 \%)$ are therefore not insignificant, the projection error in respect of new business is qualified by the wide range of fluctuation of this variable. The projections regarding surrenders and sums insured currently in force come closer to the actual figures $(28.5 \%$ and $9.6 \%$, respectively).

It would certainly have been unreasonable to expect these intitial statements to provide an exact projection of the actual development. In addition, it is not the usual practice, e.g. in economic research institutes, to base projections solely on the results of mathematical regressions. The projections actually published are always figures adjusted on the basis of findings which mathematical regressions do not take into account.

If an analogue approach had been taken in the present case, the calculations would also have resulted in better estimates. One of the basic variables of the projections for life assurance is represented by the feelings and expectations described as the psychological climate in society. The time series of this Allensbach Indicator taken as a basis shows three extreme values during the period 1949 to 1981 , namely for the years 1950,1973 and 1980. An inquiry into the reasons for these extreme values shows that in those years the time at which the opinion poll was conducted always coincided with a political crisis : 
the Korean crisis in 1950, the oil price crisis in 1973 and the Polish crisis as well as the outbreak of war between Iran and Irak in 1980.

Hence, it was invariably political anxiety which was reflected in a sharp abatement of hopes in respect of the new year. Such index values marked by momentary anxiety are without doubt not suitable for being included into the calculation of the indicators of life assurance business unless they are "adjusted". A simple calculation shows the possible nature of such an adjustment and the extent to which it would have helped to improve the results. On the assumption that half of the sharp decrease of the Allensbach Indicator in 1981 from 51 to 34 was due to special political factors, the calculation produces the adjusted projected values shown in the addendum next to the unadjusted values.

Naturally, errors can also be found in the adjusted estimation for $198 \mathrm{l}$ and the estimation for 1982 not affected by these special influences. Table 5 in the addendum shows a comparison of estimated and actual figures for 1981 and 1982. On the whole, these projection errors are relatively small and should give cause for further research.

One of the particular advantages of such quantitative projections over more or less intuitive "expert projections" is that the former can be systematically improved. With a systematic comparison of estimated and actual figures one is therefore able in the course of time to select from a multitude of possible projections those with the greatest accuracy. In the mathematical projection models which are " able to learn ", allowance can be made for deviations of the actual from the projected development by carrying out successive adjustments until the model has the degree of accuracy required.

It would be appropriate to use the regressions described above only to make short-term projections in respect of the development of the life assurance industry. Their inclusion into company-related planning and projection models certainly requires further adjustments in accordance with the specific conditions of the individual company.

\section{LITERATURVERZEICHNIS}

A. P. BÄUMER / P. GESSNER, Die Problematik der Wertsicherung in der Lebensversicherung, in : Festschrift für Alex Möller zum 75. Geburtstag, Karlsruhe 1978, S. $199 \mathrm{ff}$.

F. BECKER, Analyse und Prognose von wirtschaftlichen Zeitreihen in der deutschen Schaden- und Unfallversicherung, Karlsruhe 1982.

R. BERGLER, Psychologie in Wirtschaft und Gesellschaft, Köln 1982.

H.-J. EHLER, Lebensversicherung - Von der Marktsättigung noch ein gutes Stück entfernt, in : Handelsblatt 17.7.1980.

W. B. EMDE, Anwendung von Zeitreihenanalyse- und Prognosemethoden im Versicherungsunternehmen, in : TICA $21,1980, \mathrm{~S} .83 \mathrm{ff}$.

W. FRERICHS / K. KÜBLER, Gesamtwirtschaftliche Prognoseverfahren, München 1980.

E. HELTEN, Methoden und Grenzen der Prognose in Versicherungsunternehmen, in : Zeitschrift für die gesamte Versicherungswissenschaft, ZVersWiss, 3/1981, S. $335 \mathrm{ff}$.

E. HELTEN, Die Bedeutung der Konjunkturforschung für die Versicherungswirtschaft, in: Versicherungswirtschaft (VW) $1 / 78$, S. $12 \mathrm{ff}$. 
H. HENSCHEL, Wirtschaftsprognosen, München 1979.

Jahrbuch des Verbandes der Lebensversicherungs-Unternehmen, verschiedene Jahrgänge.

G. LASKOWSKI, Auswirkungen der Bevölkerungsentwicklung in der Bundesrepublik Deutschland auf die L.ebensversicherung, in : ZVersWiss, 1,2/1981, S. $73 \mathrm{ff}$.

D. NONHOFF, Welchen Rang hat die Geldwertstabilität für die Lebensversicherung?, in: VW $18 / 1980$, S. 1145 ff.

W. F. SCHICKINGER, Die Kapitallenkungsfunktion der Lebensversicherung in der Bundesrepublik Deutschland, Diss., Karlsruhe 1969.

R. SCHWEBLER, Geldwert und Lebensversicherung, in: A. Karmann u.a., Beiträge zur Wirtschaftspolitik, Königstein/Ts. 1981, S. 71 ff.

ders., Vorsorge im Spannungsfeld der Sozialpolitik, in : VW 1/1978, S. ff.

ders., Sicherheit zwischen Sozial- und Individualversicherung, Karlsruhe 1977.

E. UTECHT, Die Nachfrage nach Lebensversicherungsschutz, Berlin 1973.

A. WAGNER, Die Wachstumszyklen der Bundesrepublik Deutschland, Tübingen 1972.

W. WEISS, Wachstumsziele und -instrumente in Versicherungsunternehmen Diss., Köln 1975.

K. H. WESSEL, Aufgabe und Rolle der privaten Lebensversicherung, in : Arbeit und Sozialpolitik 2/78. ders., Die eigenverantwortliche Vorsorge erweist sich als starkes Sparmotiv, in : Handelsblatt, 20.5. 1981. ders., Lebensversicherer vor vielschichtigen Problemen, aber nicht unzufrieden, in : VW 11/82, S. $60 \mathrm{ff}$.

\section{Addendum}

\section{Explanations concerning tables $1-4$}

1 The multiple regressions are linear functions in the following form : $y=a+b_{1} x_{1}+\ldots+b_{n} x_{n}$

$Y$ is the dependent variable, $a$ the absolute term, $b_{1}, \ldots, b_{n}$ the regression coefficients and $x_{1}, \ldots, x_{n}$ the values of the independent variable.

2 The regression coefficients and in brackets below the appropriate $t$-values are indicated for each of the independent variables. If possible, the $t$-values ought to be greater than 2 or less than -2 , so that it can be assumed that the regression coefficients are different from 0 .

3 The Dumny-variable only takes the values 0 or 1 . It allows one in this case to eliminate special influences such as the " measures of exemption " form statutory pension insurance or the inclusion of life assurance into the $624 \mathrm{DM}$ Law.

${ }_{4}$ The multiple correlation coefficient, the multiple determination coefficient and the Durbin-Watson-Coefficient (DW-value) are indicated for the purpose of judging the different statements. The multiple determination coefficient which, as the square of the multiple correlation coefficient, can take values between 0 and 1 , indicates what percentage of the variation of the dependent variable can be described by the regression statement (e.g. $1=100 \% ; 0.86=86 \%$ ). The DW-value is a test variable for the first-order autocorrelation. With values around 2 the existence of an auto-correlation can be excluded. 


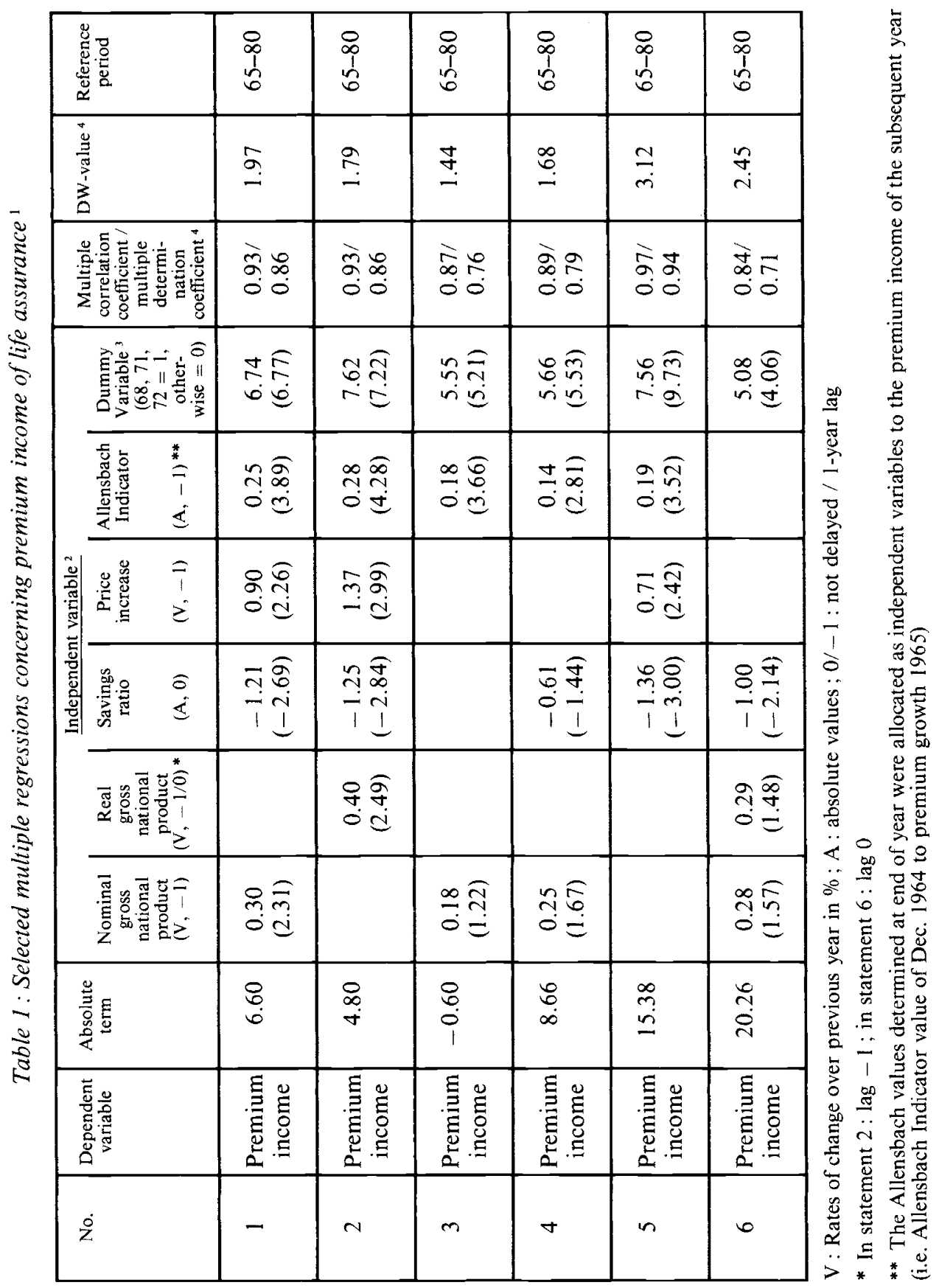




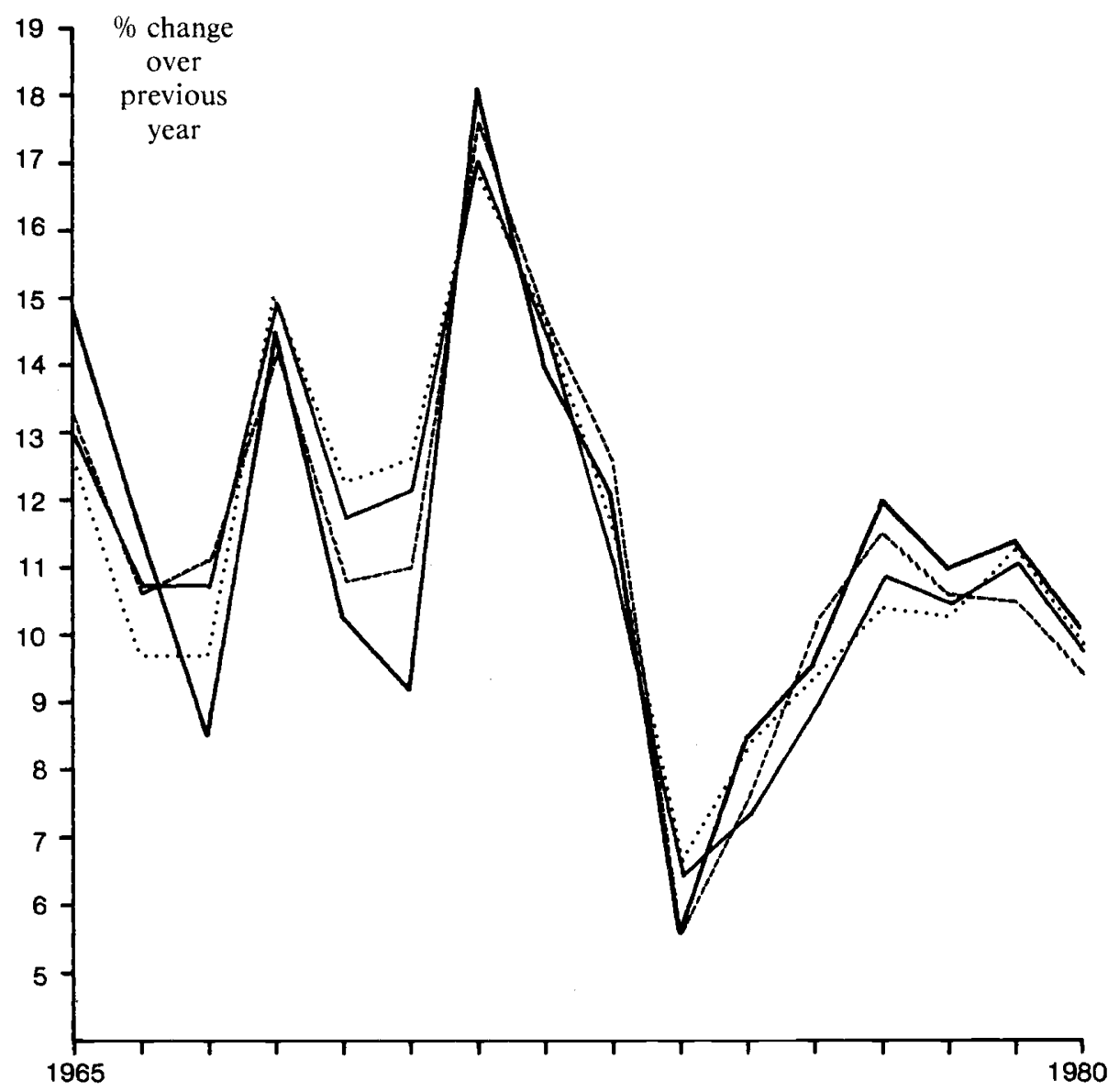

actual development

- - - - - statement no. 1 , table 1 statement no. 2 , table 1 statement no. 3 , table 1 


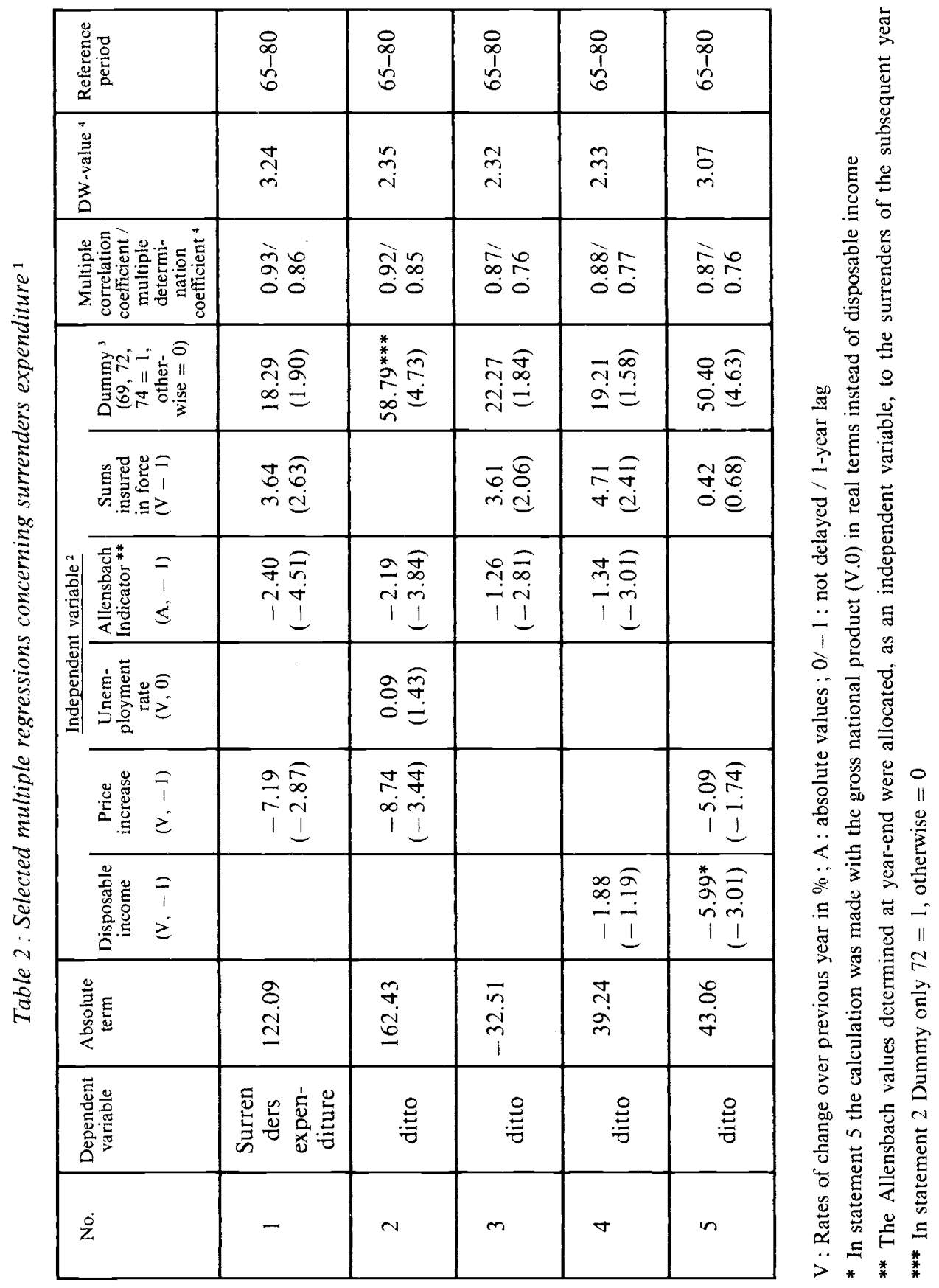


Diagram 2 : Surrenders expenditure

Comparison of the actual development with estimated regressions

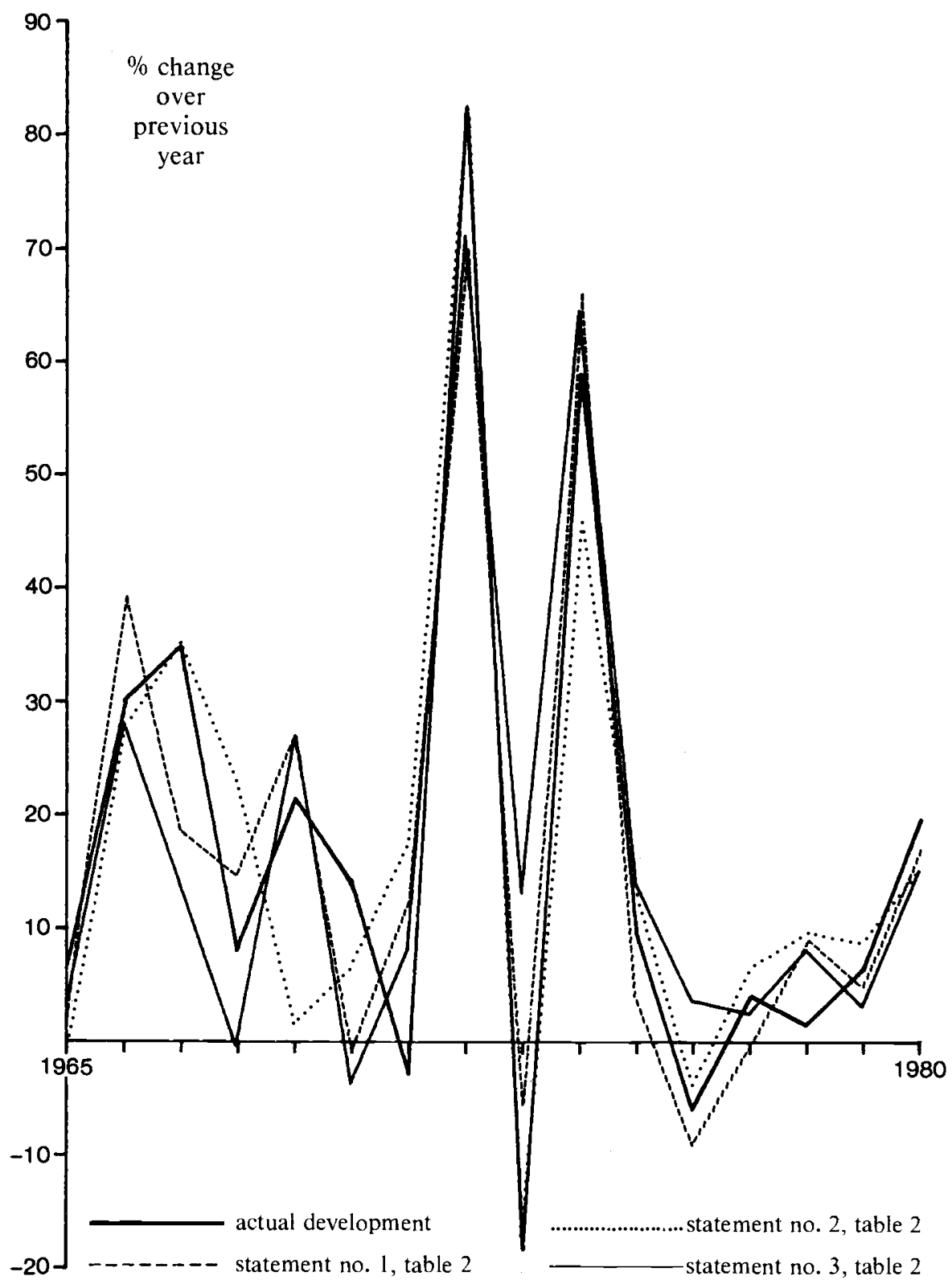




\begin{tabular}{|c|c|c|c|c|c|}
\hline 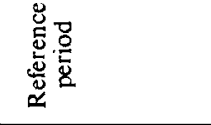 & $\begin{array}{l}8 \\
1 \\
1 \\
10\end{array}$ & $\begin{array}{l}8 \\
\infty \\
1 \\
6 \\
6\end{array}$ & $\begin{array}{l}8 \\
\infty \\
1 \\
1 \\
0\end{array}$ & $\begin{array}{l}8 \\
1 \\
1 \\
2\end{array}$ & \\
\hline 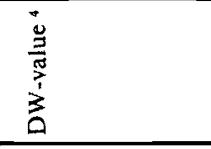 & $\stackrel{\bar{\sigma}}{-}$ & 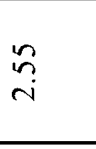 & $\stackrel{\infty}{\infty}$ & $\underset{\text { ¿ }}{\text { i }}$ & \\
\hline 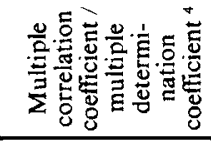 & $\begin{array}{l}\bar{a} \\
\dot{\sigma} \\
\dot{0}\end{array}$ & 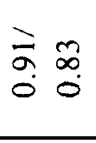 & $\begin{array}{ll}\grave{2} & 0 \\
\vdots & \infty\end{array}$ & $\begin{array}{ll}\infty & \hat{1} \\
\infty & 0 \\
0 & 0\end{array}$ & \\
\hline 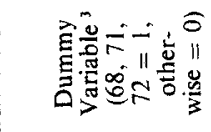 & $\begin{array}{l}\sigma \hat{m} \\
\dot{\sigma}\end{array}$ & 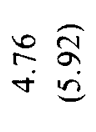 & 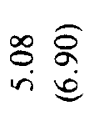 & 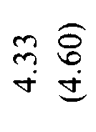 & $\underset{\Xi}{\mathbb{E}}$ \\
\hline 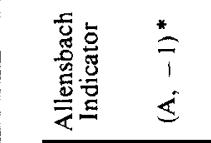 & 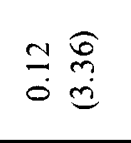 & & 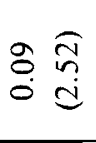 & & 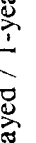 \\
\hline 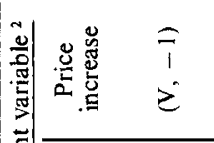 & & & & 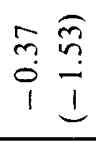 & $\begin{array}{l}\frac{0}{0} \\
\vdots \\
0 \\
\ddot{0} \\
\end{array}$ \\
\hline 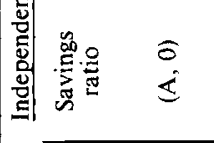 & & $\begin{array}{ll} & \widehat{a} \\
\infty & 0 \\
0 & i \\
1 & 1\end{array}$ & 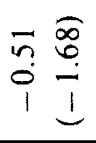 & & 命 \\
\hline 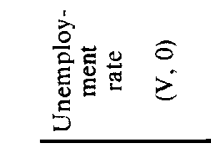 & & 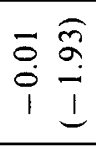 & & $\begin{array}{ll}\overline{0} & 0 \\
0 & 0 \\
0 & 0 \\
1 & 1\end{array}$ & 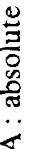 \\
\hline 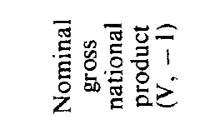 & $\begin{array}{ll}\pi & \widetilde{2} \\
0 & a\end{array}$ & 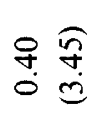 & 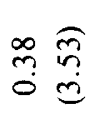 & $\begin{array}{l}\bar{m} \\
\vdots \\
0\end{array}$ & 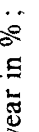 \\
\hline 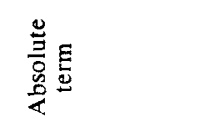 & $\begin{array}{l}\stackrel{\circ}{\sim} \\
\text { i }\end{array}$ & $\begin{array}{l}\sigma \\
\sigma \\
a\end{array}$ & $\begin{array}{l}n \\
0 \\
0\end{array}$ & $\stackrel{\circ}{\circ}$ & .气 \\
\hline 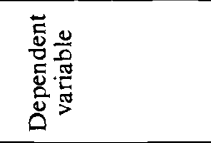 & 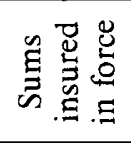 & $\stackrel{ }{:}$ & $\stackrel{ }{\stackrel{⿹}{0}}$ & $\stackrel{?}{:}$ & 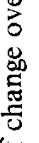 \\
\hline$\dot{z}$ & - & $N$ & $m$ & $\nabla$ & $\underset{\mathscr{U}}{\mathscr{\mathscr { U }}}$ \\
\hline
\end{tabular}




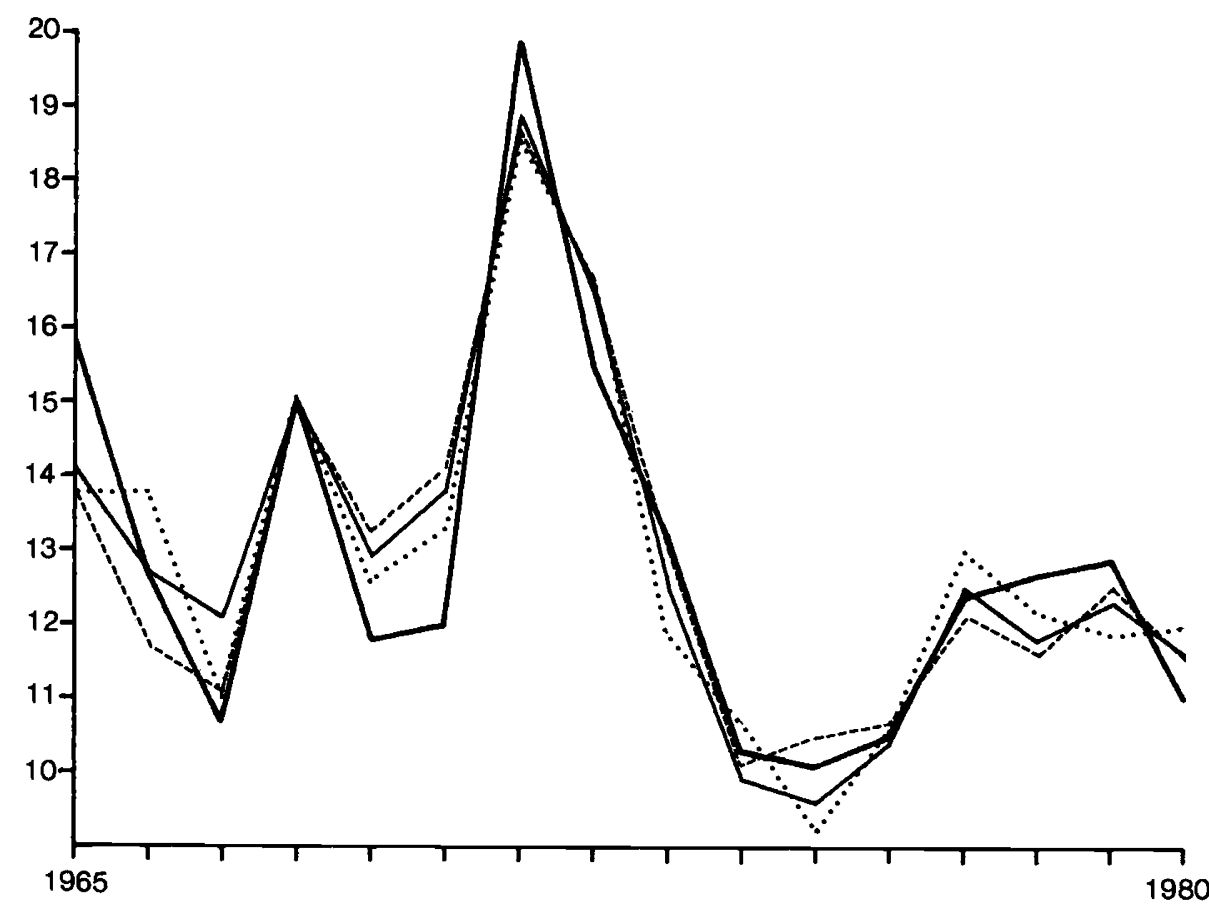

actual development

-..--- statement no. 1 , table 3

statement no. 2 , table 3

statement no. 3 , table 3 


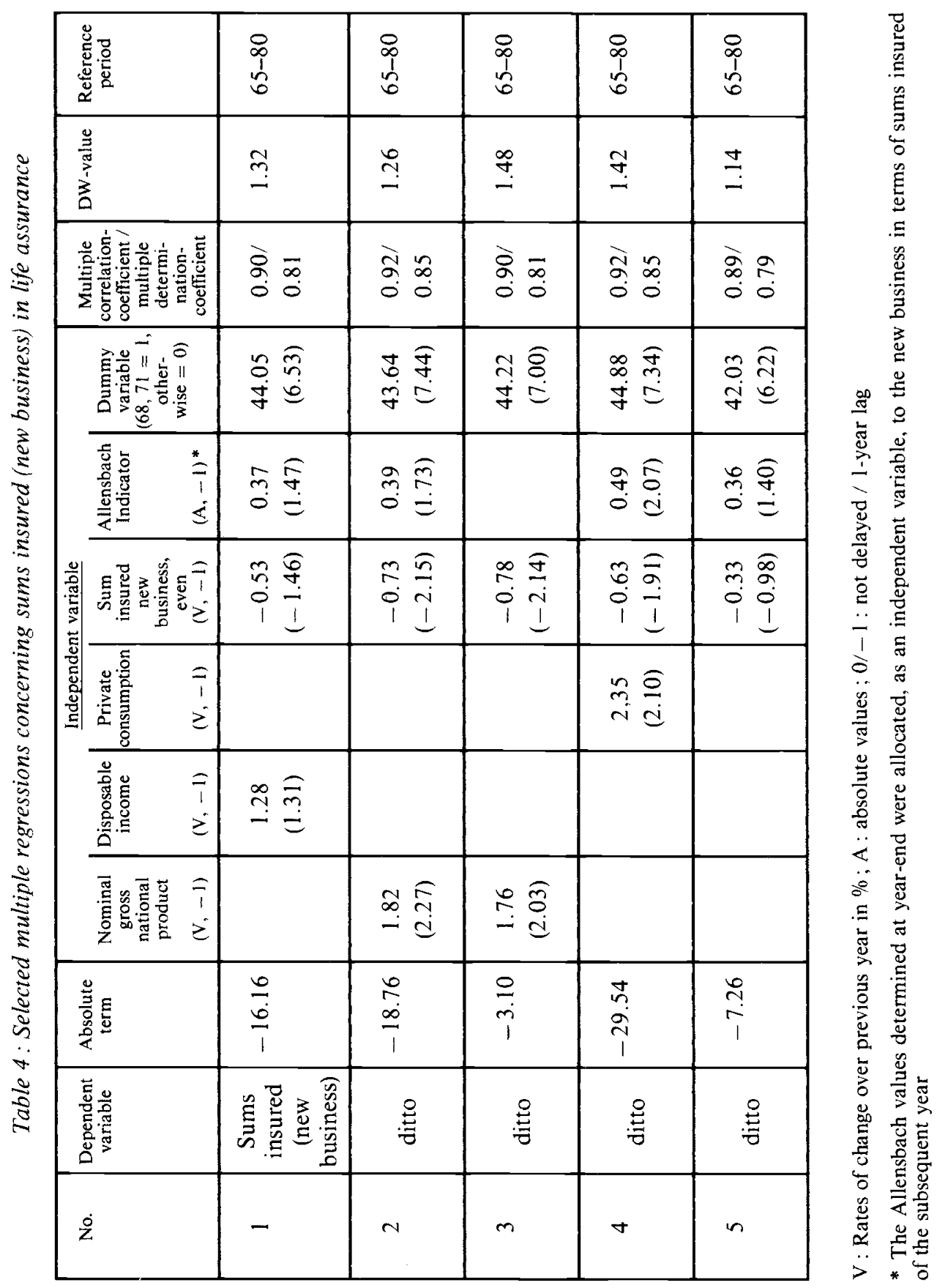


Diagram 4: New sums insured

Comparison of the actual development with estimated regressions

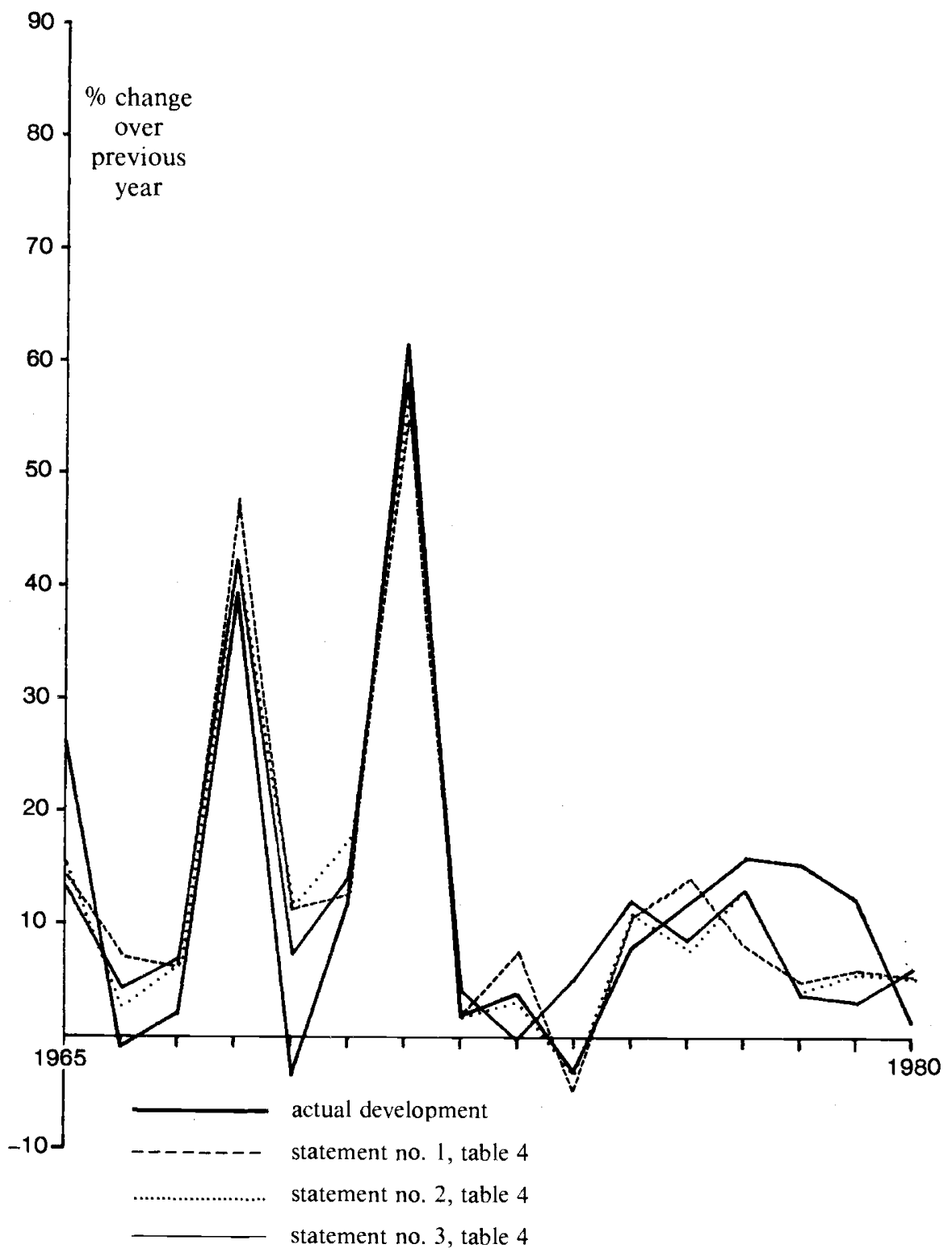




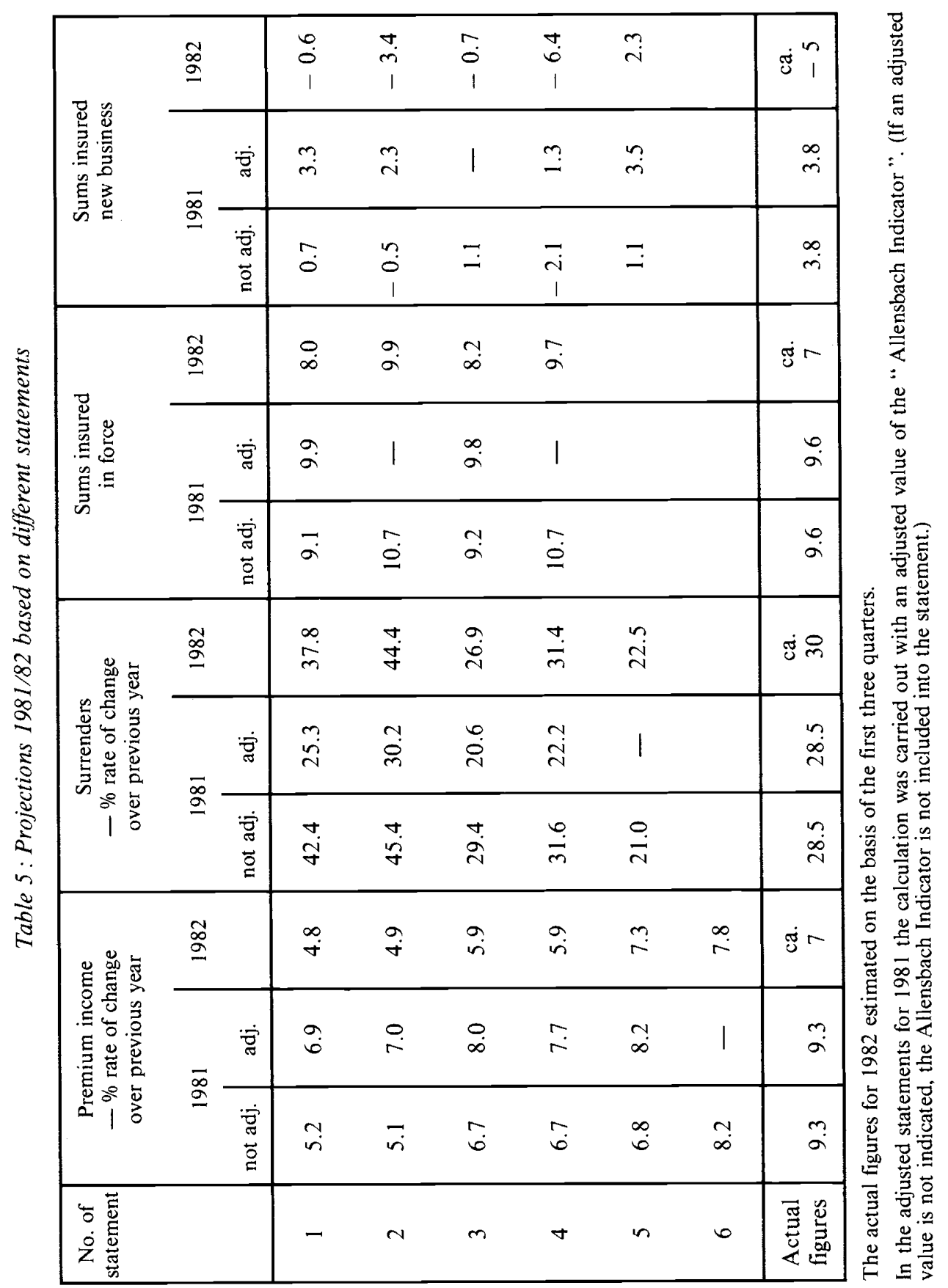

